\title{
READING SŎKTOK KUGYŎL MATERIALS BASED ON $\breve{O}_{N H A E}$ MATERIALS
}

\author{
Satoshi JOHO \\ University of Toyama \\ joho@hmt.u-toyama.ac.jp
}

\begin{abstract}
In this paper, we discussed some advantages of and points of attempt to research how to read Hancha (漢字) with Kugyŏl (口訣) markings based on the premise, that the tradition of Hanmun Hundok (漢文訓讀) in Sŏktok Kugyŏl (釋讀口訣) materials has been succeeded to Ŏnhae (諺解) materials since the mid-15th century, the promulgation of Hunmin Chyŏngŭm (訓民正音), and based on Ŏnhae (諺解) system in these Ŏnhae (諺解) materials. As a result, Hundok (訓讀) systems of Sŏktok Kugyŏl (釋讀口訣) materials had much resemblance to the Non-Buddhist (Confucian) Ónhae (諺解) materials since the end of 15th century. Therefore, Non-Buddhist (Confucian) Ŏnhae (諺解) materials occupy an important position to consider the reading methods of Sŏktok Kugyŏl (釋讀口訣) materials.
\end{abstract}

Keywords: reading method; Sŏktok Kugyŏl (釋讀口訣) materials; Ŏnhae (諺解) materials; Hanmun Hundok (漢文訓讀); Kakikudashibun (書き下し文); Non-Buddhist (Confucian) group; Korean language

\section{Povzetek}

In this paper, we discussed some advantages of and points of attempt to research how to read Hancha (漢字) with Kugyŏl (口訣) markings based on the premise, that the tradition of Hanmun Hundok (漢文訓讀) in Sŏktok Kugyŏl (釋讀口訣) materials has been succeeded to Ŏnhae (諺解) materials since the mid-15th century, the promulgation of Hunmin Chyŏngŭm (訓民正音), and based on Ŏnhae(諺解) system in these Ŏnhae(諺解) materials. As a result, Hundok (訓讀) systems of Sŏktok Kugyŏl (釋讀口訣) materials had much resemblance to the Non-Buddhist (Confucian) Ónhae (諺解) materials since the end of 15th century. Therefore, Non-Buddhist (Confucian) Ornhae (諺解) materials occupy an important position to consider the reading methods of Sŏktok Kugyŏl (釋讀口訣) materials.

Ključne besede: metode branja; Sŏktok Kugyŏl (釋讀口訣) gradiva; Ŏnhae (諺解) gradiva; Hanmun Hundok (漢文訓讀); Kakikudashibun (書き下し文); ne-budistična (konfucijanska) group; korejski jezik

Acta Linguistica Asiatica, 4(1), 2014.

ISSN: 2232-3317, http://revije.ff.uni-lj.si/ala/

DOI: 10.4312/ala.4.1.43-68 


\section{Introduction}

There are a lot of various researches to define how to read individual Chinese characters, Hancha (漢字) with Kugyŏl (口訣) markings in Koryǒ-era (高麗時代) Sǒktok Kugyŏl (釋讀口訣) materials, that is, to refer to other materials (e.g, (1)Ch'acha P'yogi (借字表記) materials such as Hyangga (㰾歌), Idu (吏讀), (2)Hancha (漢字) dictionaries published since the 16th century, (3)Interpretation of Hancha (漢字) which is written in the additional annotation of Onhae (諺解) texts, etc.). However, it seems that these researches tend to treat these multifarious materials arbitrarily, and only few researches treat the materials systematically on the consistent policy.

In this paper, we will discuss some advantages and points of attempt to research how to read Hancha (漢字) with Kugyŏl (口訣) markings based on the premise, that the tradition of Hanmun Hundok (漢文訓讀) in Sóktok Kugyŏl (釋讀口訣) materials has been succeeded to Ornhae (諺解) materials since the mid-15th century, the promulgation of Hunmin Chyŏngŭm (訓民正音), and based on Ŏnhae (諺解) system in these Ŏnhae (諺解) materials.

\section{Procedure for discussions}

In this chapter, we will discuss the following points as the procedure for discussions.

(1) Hanmun Hundok (漢文訓讀) is a linguistic activity in wide East Asian region where Chinese characters are used.

(2) Both $\breve{U m d o k}$ (音讀) and Hundok (訓讀) had been used to read Hanmun (漢 文) texts since ancient times in Korea

(3) In Korea, both Ǔmdok (音讀) and Hundok (訓讀) were prerequisites to learn Hanmun (漢文) texts.

(4) The order of reading was always consistent, that is to read $\breve{U m d o k}$ (音讀) first, and after that to read Hundok (訓讀).

(5) Han'gŭl Kugyŏlmun (한글 口訣文) and Ŏnhaemun (諺解文) of Ŏnhae (諺 解) materials are respectably projections from the Ǔmdok (音讀) and Hundok (訓讀) of Hanmun (漢文) texts' readings since ancient times.

(6) Ǒnhaemun (諺解文) of Ornhae (諺解) materials can be regarded as Kakikudashibun (書き下し文), as the results of Hanmun Hundok (漢文訓讀).

\section{1}

There is no need to dwell on the subject no longer ${ }^{1}$ that Hanmun Hundok (漢文訓 讀) is a linguistic psychology not only in Japan but also in wide East Asian region

\footnotetext{
${ }^{1}$ Kosukegawa [小助川貞次] $(2009,2010)$ named Hanmun Hundok(漢文訓讀) in wide East Asian region where Chinese characters are used, 'East asian version of globalization'.
} 
where Chinese characters are used. Korea is not an exception, and it has been cleared both in name and in reality. The fact that Hanmun Hundok (漢文訓讀) had once existed in Korea is proved by both the historical sources and existing Sŏktok Kugyŏl ( 釋讀口訣) materials such as Jiùyì Rénwángjīng (舊譯仁王經).

（1）薛聰 字聰智 祖談捺奈麻 父元曉 初爲桑門 淹該佛書 既而返本 自號小性 居士 聰性明鋭 生知道術 以方言讀九經 訓導後生 至今學者宗之 又能屬 文而世無傳者但今南地 或有聰所製碑銘 文字缺落不可讀 竟不知其何如 也 (Samguk Sagi [三國史記] 巻46 列伝 薛聰)

(2) 公主果有娠 生薛聰 聰生而裔敏 博通經史 新羅十賢中一也 以方音通會華 夷方俗物名 訓解六經文學 至今海東業明經者 傳受不絶 (Samguk Yusa [三 國遺事] 巻4 義解 元曉不覊)

These sources of Samguk Sagi (三國史記)[1145] and Samguk Yusa (三國遺事) [late 13th century] were quite often referred to in the discussions about the development of Ch'acha P'yogipöp (借字表記法) in Korea. ${ }^{2}$

It is, therefore, that both $\breve{U m d o k}$ (音讀) and Hundok (訓讀) had been used to read Hanmun (漢文) texts in the past, but afterward "Hundok (訓讀) was renounced" (Yoshida [吉田金彦], Tsukisima [築島 裕], Ishizuka [石塚晴通], \& Tsukimoto [月本 雅幸] (eds.), 2001, p. 2) in Korea.

\section{2}

About Ǔmdok (音讀) and Hundok (訓讀) of Hanmun(漢文) texts reading, Nam [南豊鉉] (1988/1999, p. 26) pointed out that Sǒktok Kugyŏl (釋讀口訣) arose first and after that Ǔmdok Kugyŏl (音讀口訣) advanced in Koryŏ-era (高麗時代). It means that only Ǔmdok (音讀) existed in the past, and Hundok (訓讀) arose in Koryó-era (高麗時 代). But both Ǔmdok (音讀) and Hundok (訓讀) had been used since ancient times.

In this context, Ogura [小倉進平] (1934/1975, pp. 363-369) once pointed out about the reading of Hanmun (漢文) texts initiated to Japan by Ajikki (阿直岐) and Wangin (王仁), as below.

(1)Ajikki (阿直岐) and Wangin (王仁) would have read Hanmun (漢文) as Chiktok Hyŏnt'o (直讀懸吐), in Paekche pronunciation (百済音) or Wú pronunciation (呉音) of Chinese characters.

(2)After Chiktok Hyŏnt’o (直讀懸吐), Ajikki (阿直岐) and Wangin (王仁)

2 For example, Ogura [小倉進平] (1934/1975, p. 364), Chŏng [鄭寅承] (1957/1997, pp. 120122), Nakamura [中村 完] (1976/1995, pp. 38-39), Nam [南豊鉉] (1997/1999, p. 40), An [安 秉禧] (2001a/2009b, pp. 21-22, 2001b/2009b, pp. 47-48), and so forth. 
would have translated into Korean sentences, with original Korean words and Korean pronunciation of Chinese characters.

(3) Japanese could not have handed down the method of Chiktok Hyŏnt'o (直 讀懸吐).

(4) Japanese would have invented Japanese Kundoku method (訓読法), on the model of Korean Hundok method (訓讀法).

Of these, it is important that both $\breve{U m d o k}$ (音讀) and Hundok (訓讀) had been used in Paekche (百済). Also, it seems important points that he equated the form of Ŏnhaemun (諺解文) in Ǒnhae (諺解) materials with Hanmun Hundok (漢文訓讀), and that "We have to consider that the step Chiktok Hyont'o (直讀懸吐) is mandatory, at least once to reach the step of Hunsŏk (訓釋)" (Ogura [小倉進平], 1934/1975, p. 364). It is, therefore, the order that $\breve{U} m d o k$ (音讀) arose first and after that Hundok (訓 讀) advanced, such as Nam [南豊鉉] (1988/1999, p. 26) is not correct, but the opposite order is correct. Ogura's viewpoint was quite appropriate in his days in spite of the lack of existing materials, ${ }^{3}$ because Sóktok Kugyŏl (釋讀口訣) materials had not been found in those days.

\section{3}

It is said that both Ǔmdok (音讀) and Hundok (訓讀) were requisites to learn Hanmun (漢文) texts. About this, An [安秉禧] (1976/1992a, pp. 299-230) pointed out in detail the learning method of Hanmun (漢文) texts in the educational institution for the King[Here, King Sŏnjo(宣祖)] called Kyŏngyŏn(經笜), with Yu Hŭich'un (柳希春) [1513 1577]'s diaries as below. (An [安秉禧], 1976/1992a, p. 299, Referred with some expressions changed.)

上讀前受一次 玉音琅琅 臣以經筵上番 進講大學正心章 自所謂修身在正 其心 至或不能不失其正矣 音讀二度 釋一度 上即音讀一度 釋一度荁 (Miam Sŏnsaengjip [眉嚴先生集] 巻15 經筵日記 丁卯[1567年]11月5日)

(5) 書講 希春與柳濤入侍 右承旨朴承任 特進官南應雲 柳景深同入 希春講大 學或問格物致知章 上讀音一遍 臣誤説補亡章之義 上曰時未釋姑停之 臣 即伏地 侯御釋荁 (Miam Sŏnsaengjip [眉嚴先生集] 巻16 經筵日記 庚午

${ }^{3}$ However, it does not mean that no foundation is found in his argument that Japanese were initiated into the reading of Hanmun (漢文) texts by Ajikki (阿直岐) and Wangin (王仁) as the order (3). Ogura [小倉進平] (1934/1975, pp. 366-367) gives two kinds of indirect evidences, one is a custom of Onkun Heisho (音訓並唱) called Monzen Yomi (文選読み), and the other is a characteristic of Okuriji (送り字) in Senmyo (宣命) and Norito (祝詞) called Senmyo Gaki (宣命書き). Incidentally, Nakada [中田祝夫] (1954/1979, pp. 5-40) argues that $\breve{U m d o k}$ (音讀) reading of Hanmun (漢文) texts also would have existed in Japan, based on the various sources. 


\title{
[1570年]7月17日)
}

This applies to the educational institution for the princes called Sŏyŏn (書筵).

\begin{abstract}
卯時入書䇥講心經 東宮具法服 西向坐 賓客北向坐 春坊上下番及余俱東 向南上 俯伏各展所講章以聽 東宮講前受音 [前日課讀 謂之前受音] 不遠 復章畢 上番講新受音 [當日所講謂之新受音] 子絶四 [止] 固如此也 讀荁 東宮又讀一遍 上番遂解釋文義以奏 [講事皆上番主張] 下番又畧奏 (Sunam Sŏnsaeng Munjip [順菴先生文集] 巻16 雜著 壬辰桂坊日記[1772 年] 5月28日)
\end{abstract}

The order of reading that to read Ǔmdok (音讀) at first, and after that to read Hundok (訓讀) in these sources, is common to Ogura's viewpoint that "the step Chiktok Hyŏnt'o(直讀懸吐) is mandatory, at least once to reach the step of Hunsŏk (訓 釋)”. (Ogura [小倉進平], 1934/1975, p. 368)

The learning style of Hanmun (漢文) texts can be seen from the Kugyó l(口訣) materials in early Chosŏn-era (朝鮮時代). (Nam [南豊鉉], \& Sim [沈在箕], 1976/1999, p. 78).

Of these, (b) (d) have two kinds of Kugyŏl (口訣) markings, Ǔmdok Kugyŏl (音 讀口訣) and as a kind of Sŏktok Kugyŏl (釋讀口訣). It is important that Ümdok Kugyŏl (音讀口訣) markings are always on the right side without exception. Sŏktok Kugyŏl (釋讀口訣) markings are basically on the left side, but exceptionally on the right side if there is any space. And when the both coincide, Kugyŏl (口訣) markings are only on the right side, because Ümdok Kugyŏl (音讀口訣) marked previously also serves as two kinds of Kugyŏl (口訣) markings. This is the result of the order that is to read Ǔmdok (音讀) first, and after that to read Hundok (訓讀), Nam [南豊鉉], \& Sim [ 沈在箕] (1976/1999, p. 78) noted, and this is consistent with the order of Hanmun (漢 文) texts learning as mentioned above. ${ }^{4}$

4 Incidentally, in example (a), of Wŏn'gakkyŏng Kugyŏl (圓覺經口訣), there are a lot of Sŏktok Kugyŏl (釋讀口訣) marking on the right side. But we will have to pay attention to that this material have different aspects from another (b) (d) materials. In this material, Han'gŭl Kugyŏl (한글 口訣), that corresponded to Ümdok (音讀), is already printed in the texts. And according to this, it had been possible to read Ümdok (音讀). In other words, it have not necessary to dare to mark Ümdok Kugyŏl (音讀口訣), and so there are any spaces both on the right side and the left side. Then, there are a lot of Sŏktok Kugyŏl (釋讀口訣) markings on the right side. Thus, it seems that this example of Wŏn'gakkyŏng Kugyŏl (圓覺 經口訣), is also the result of the order that is to read Ümdok (音讀) at first, and after that to read Hundok (訓讀), and is the example to support the order of Hanmun (漢文) texts learning as mentioned above. 
(7)
(d)
(C)
(b)
(a)

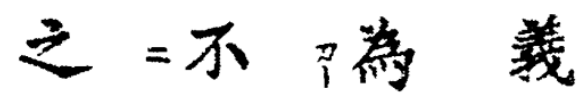

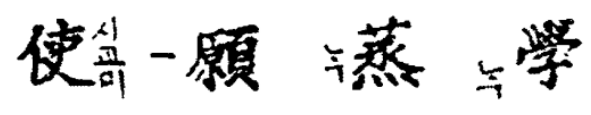

造而超少

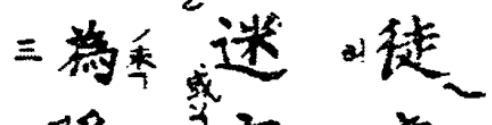



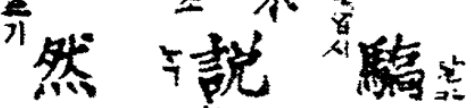

热 会 多管

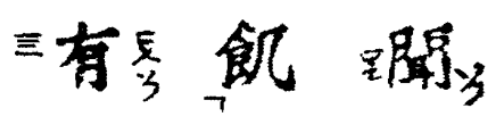

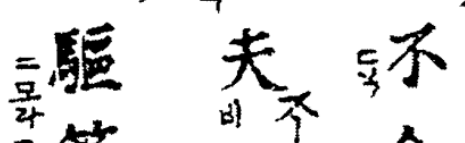

策。

栓

ifi]

道



裹能一建交奇特登

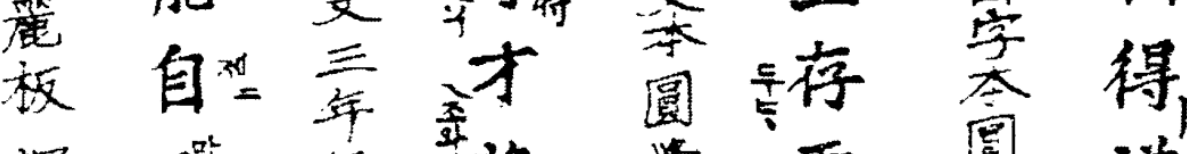

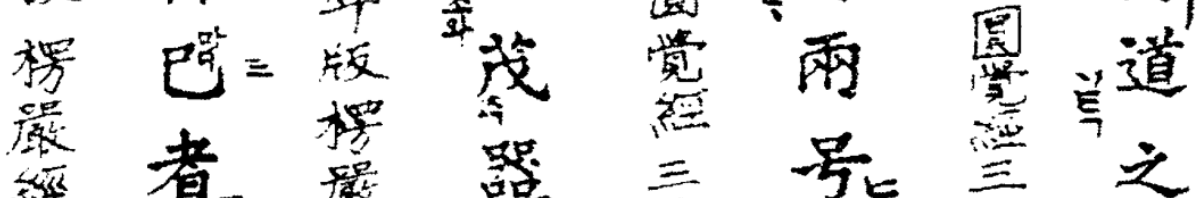



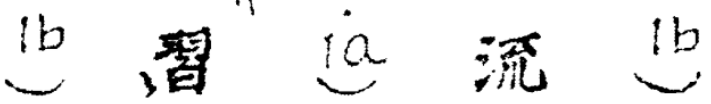



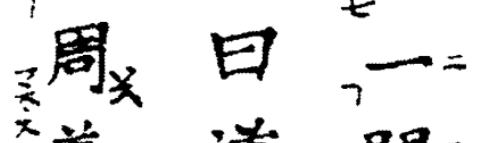

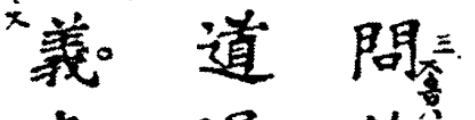

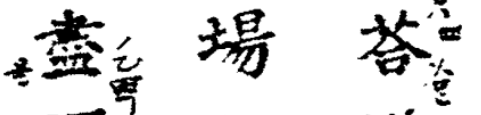

碂 4 이 道

速范

妾五

名怘

空第=

坴要三

当本整-

場

加

行与

下

根

修

題。證

坛且醇 401

号姿篭之

产壮虎

ia $z$ 


\section{4}

On the other hand, the typical structure of Ŏnhae(諺解) materials since the mid15th century, the promulgation of Hunmin Chyŏngŭm(訓民正音), at first used Kugyŏlmun(口訣文), Hanmun(漢文) with Han'gŭl Kugyŏl(한글 口訣) and after that used Ŏnhaemun(諺解文).

（8） a. 阿難이 見性 $\square$ 고 未能證入호미 譬遇華屋 $\square$ 야 不得其門 $\square \square$ 야 遂請修行方便 $\square \square$ 오니 前에 示眞基 $\square$ 則華屋之址也 1 오 此애 示眞要 $\square$ 則華屋之門也 | 니

b. 阿難이 性을 보고 能히 證 $\square$ 야 드디 몯호미 가 $\square$ 비건댄 빗난 지블 맛나 그 門 $\square$ 得디 몯 $\square \square$ 야 修行 $\square \square$ 方便을 請 $\square \square$ 오니 알 $\square$ 眞實入 터흘 뵈샤 $\square$ 빗난 지빗 터히오 이 $\square$ 眞實入 조 $\square \square$ 왼 거슬 뵈샤 $\square$ 빗난 지빗 門이니 (Nŭngŏmgyŏng Ŏnhae [楞嚴經諺解] 5:1a-1b_解)

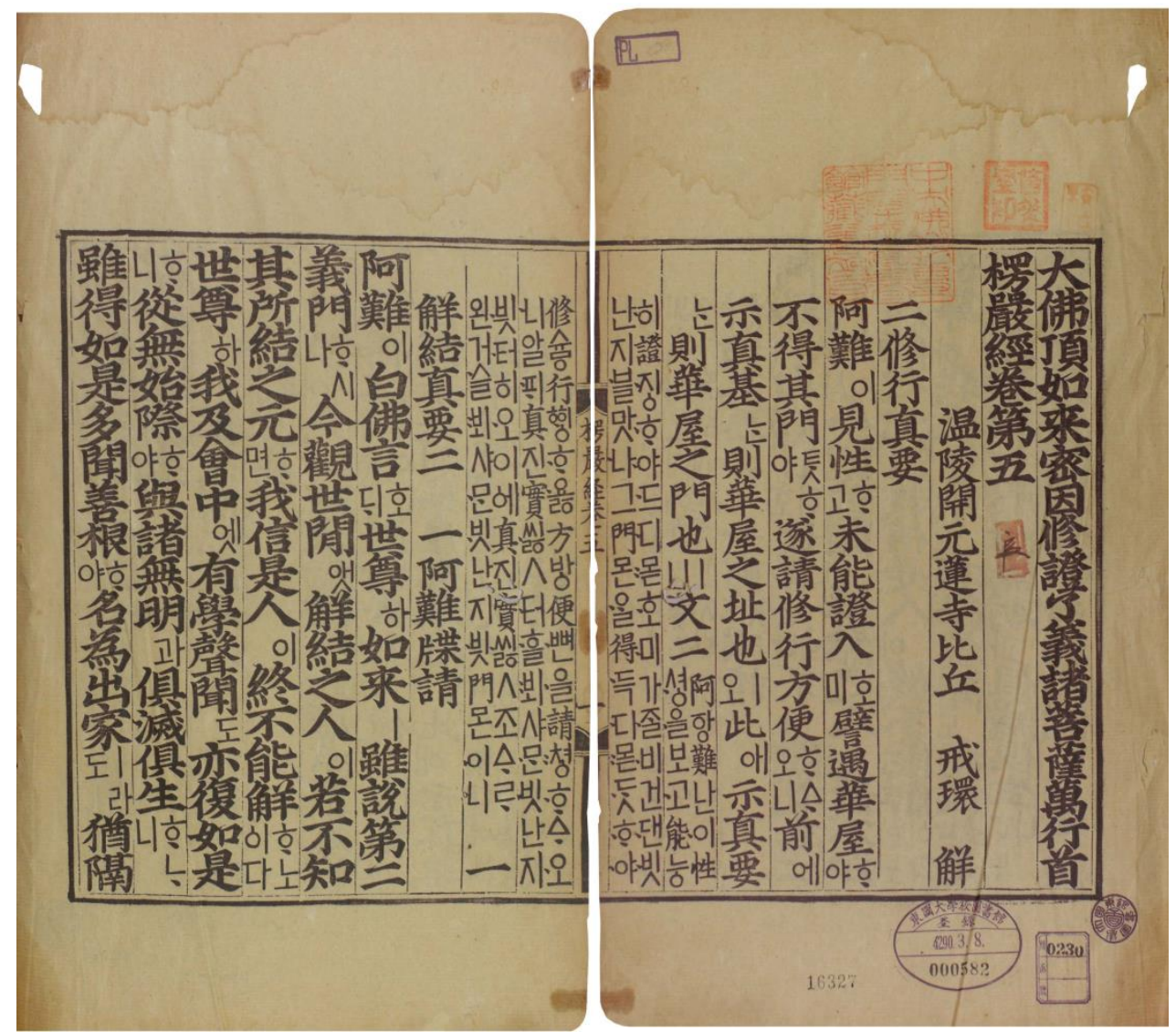

Picture 1: Relevant parts in (8) (Owned by Tongguk University (東國大學校)) 
In these materials, Kugyŏlmun (口訣文), Hanmun (漢文) attached with Han'gŭl Kugyŏl (한글 口訣), corresponds to Ǔmdok Kugyŏl (音讀口訣) which is used before the promulgation of Hunmin Chyŏngŭm (訓民正音). On the other hand, it seems that Ónhaemun (諺解文) also correspond to the result of Hundok (訓讀) reading, so to say, it resembles to Kundokubun (訓読文), Yomikudashibun (読み下し文), or Kakikudashibun (書き下し文) of Japanese Kanbun Kundoku (漢文訓読). Therefore, it seems that Kugyŏlmun (口訣文) and Ŏnhaemun (諺解文) of Ŏnhae (諺解) materials are each projections from the Úmdok (音讀) and Hundok (訓讀) of Hanmun (漢文) texts reading. It is thought that the order that Kugyŏlmun (口訣文) were written at first and after that Ŏnhaemun (諺解文) were written, was not unrelated to the order of Hanmun (漢文) text's reading since ancient times. ${ }^{5}$

In addition, the order of Hanmun (漢文) texts reading corresponds with the process of completing Ŏnhaemun (諺解文) as follows.

a. 恭惟我主上殿下 天從聖學崇信是經緬思遺囑之重篤念繼述之考 萬機 之暇 特徹乙覽 親加口訣 正其句讀 命工曹參判臣韓繼禧及臣守温 悉 以國語依文而譯 於是親定倠校 質諸信眉等名僧 旋下校書館 隨即模印 始於是年六月至冬十月而事巳成矣 (Nüngŏmgyŏng Ŏnhae [楞嚴經諺 解] 御製跋)

b. 辛巳夏如來舎利分身於檢巖 於大内者現有百餘枚 祥光異端振古所無 一國臣民皆生希有心 上亦劤然 發大誓願 乃於六月十一日 命臣反譯楞 嚴經 召前尚州牧事金守温 於服中 開局於忠順堂之庴下 賜以親定温陵

5 Kin [金文京] (2010:99-105) pointed out that Kugyŏcha (口訣字) marked in Nŭngŏmgyŏng (楞嚴經) (Owned by Tan'guk University (檀國大學校), Tongyanghak Yŏn'guso (東洋學研 究所)) matches the relevant part of Nŭngŏmgyŏng Ŏnhae (楞嚴經諺解), and that it would be the result of either that Onhae (諺解) was created based on Hundok (訓讀), or that Hundok ( 訓讀) reading was done based on Ornhae (諺解). In this case the possibility of latter is higher, he said. However, he added, “Considering the fact that Hundok (訓讀) reading had existed prior to the promulgation of Hunmin Chyŏngŭm (訓民正音), it seems that Han'gŭl Ŏnhae (한글 諺解) was, as a whole, created based on Hundok (訓讀) reading which had existed since before.”. (pp. 104-105). On the other hand, Hong [洪允构] (1994/in press, pp. 171-175) mentioned the manuscript Ľ̀ Tàibái (李太白)'s poetry collection, seems to be written by posterity, in his possession. It consists of the following three volumes, (1) Original Hanmun ( 漢文) text of Ľ̀ Tàibái (李太白)'s poetry, (2)Hanmun (漢文) text with Kugyŏl (口訣) and interpretation markings with thin brush, (3) Onhae (諺解) text. He said that these materials are in the same person's handwriting, and purchased at the same store. Of the three volumes, Kugyŏl (口訣) and interpretation markings of (2) are similar to the Kugyŏl (口訣) markings of (7). Hong [洪允构] (1994/in press, pp. 171-175) insisted that the volume of (2) shows the preliminary stage of completing Onhae (諺解) text such as (3) volume. Even if these materials are in the same person's handwriting, it is not certain that these are copied in the order of (1) $\rightarrow$ (2) $\rightarrow$ (3) If it is true, it would be one of the materials supporting the insistence of this paper, that Ŏnhaemun (諺解文) can be regarded as Kakikudashibun (書き下し文), the results of Hanmun Hundok (漢文訓讀) reading. 
要解口訣臣等謹依口訣譯之至八月二十二日蒿成 以進 (Nŭngŏmgyŏng Ŏnhae [楞嚴經諺解] 御製跋)

c. 上이 입겨 $\square \square \square$ 샤 慧覺尊者 $\square$ 마 $\square$ 와시 $\square$ 貞嬪 韓氏等이 唱準 $\square$ 야 $\square$ 工曹參判 臣 韓繼禧 前尚州牧事 臣 金守温 $\square$ 飜譯 $\square$ 고 議政府 撿詳 臣 朴貄 護軍 臣尹顼商 世子文學 臣 盧思慎 吏曹佐郎 臣 鄭孝常은 相考 $\square$ 고 永順君 臣 溥 $\square$ 例 一定 $\square$ 고 司贍寺尹 臣 曹變安 監察 臣 趙祉 $\square$ 國韻 丛고 慧覺尊者 信眉 入選思智 學悦 學祖 $\square$ 㭛譯 正 $\square$ 온 後에 御覽 $\square$ 샤 一定커시 $\square$ 典言 曹氏 豆大 $\square$ 御前에 㭛譯 넑 $\square$ 오니라 (Nüngŏmgyŏng Ŏnhae [楞嚴經諺解] 御製跋)

These sources, referred to frequently (Kim [金完鎭], 1960, pp. 73-74), Shibu [志 部昭平], 1983, pp. 7-9, An [安秉禧], 1997/2009, pp. 272-276, etc.), show the process of the completing metal movable-type prints Nŭngŏmgyŏng Ŏnhae (楞嚴經諺解) [1461] published by Kyosŏgwan (校書館), in advance of the wood block prints Nüngŏmgyŏng Ŏnhae (楞嚴經諺解) [1462] publishing. In short, it means that "King Sejo (世祖) punctuated sentences with Kugyŏl (口訣) markings at first, and after that, it was translated to Korean along these Kugyŏl (口訣) markings ” (An [安秉禧], 1985/2009, p. 39). ${ }^{6}$

6 As for the process of completing Ŏnhaemun (諺解文), there are similar mentions in another Buddhist Ŏnhae (諺解) materials published by Kan'gyŏngdogam (刊經都監). Following are some examples. (An [安秉禧], 1976/1992a, p. 289, Referred with some expressions changed.) (1) 今我聖上이 以天從辡慧로 力垂善誘 $\square$ 샤 萬幾之暇애 將使聾韾로 開明케 $\square$ 샤 於 此禪經에 親印口訣 $\square$ 시고 乃命儒臣 $\square$ 시며 招集緇流 $\square$ 샤 詳加諺釋 $\square$ 야 刊板流通 $\square$ 시니 (Sŏnjong Yŏnggajip [禪宗永嘉集] 信眉 跋)

(2) 今我聖上이 夙植勝因 $\square$ 샤 爲世導師 $\square$ 샤 續佛慧明 $\square$ 시며 萬幾之暇애 敦信是經 $\square$ 샤 深契妙理 $\square$ 샤 親定口訣 $\square$ 시고 命儒臣韓繼禧 $\square$ 샤 譯以國語 $\square$ 시고 (Kŭmganggyŏng Ŏnhae [金剛經諺解] 孝寧大君 跋)

（3）恭惟主上承天體道烈文英武殿下 握符御極 託勱臨朝 丕闡微猷 欽崇至敎既 愽綜 於群籍獨 深達於丛墳 思廣甘露之門更 布慈雲之廕 煥日新之盛德 發天從之多能 楷定口 訣於契經 發揮心法於了義 (Wŏn'gakkyŏng Ŏnhae [圓覺經諺解] 黄守臣 箋文)

Furthermore, in Kŭmganggyŏng Ŏnhae (金剛經諺解), there are also mentions in Han Kyehŭi (韓繼禧)'s afterword (跋文) and in the additional annotation, that is similar to the process of completing Nŭngŏmgyŏng Ŏnhae (楞嚴經諺解) and the participants.

(4) 予欲反譯廣布 爾其勉之 於是親定口訣 [貞嬪韓氏 御前書口訣 社堂慧瓊道然戒淵 信志道成覺珠淑儀朴氏書 口訣 兼唱準 永順君臣溥承傳出納] 臣敬依 口訣宣譯孝寧與僧 海超等 更加研究 [禮曺參議臣曺變安書國韻 工曺判書臣金守温 工曺參判臣姜希孟 承政 院都承旨臣盧思慎 參校議政府舎人臣朴楗 工曺正郎臣崔影 行仁順府判官臣趙祉 ..... 考 諸經 典言曺氏 行同判内侍府事臣安忠彦 護軍臣張末同 ..... 書㭛譯 行司勇臣張治孫臣 金今音 同承供校尉臣朴成林 ...... 唱準] 凡五日告成 即命刊經都監 鏤板印布 (Kŭmganggyŏng Ŏnhae [金剛經諺解] 韓繼禧 跋)

Shibu [志部昭平] (1983, p. 22) pointed out that the process of completing Kŭmganggyŏng Ŏnhae(金剛經諺解) in this source is remarkably similar to Nŭngŏmgyŏng Ŏnhae (楞嚴經諺 
As stated above, we discussed in detail that Ŏnhaemun (諺解文) of Ŏnhae(諺解) materials can be regarded as Kakikudashibun (書き下し文), the results of Hanmun Hundok (漢文訓讀) reading, ${ }^{7}$ and these can be regarded as a kind of Hanmun Hundok (漢文訓讀) materials. ${ }^{8}$

In this paper, we will discuss some of the advantages and points of the attempt to research how to read Sǒktok Kugyŏl (釋讀口訣) materials based on the Ǒnhae (諺解) system of Hanmun (漢文) texts in Ŏnhae (諺解) materials.

解), and that the difference from Nŭngŏmgyŏng Ŏnhae (楞嚴經諺解) is only in the printing office, Kyosŏgwan (校書館) and Kan'gyŏngdogam (刊經都監).

7 Kosukegawa [小助川貞次] (2009:42) pointed out, that such as Shomono (抄物) in Japan, Ónhae (諺解) in Korea, and Kunten (訓点) materials in Vietnam, the method to write the results of Hundok (訓讀) reading in various languages exists, instead of the marking to original Hanmun (漢文) texts. That is to say, that Ŏnhaemun (諺解文) is the results of Hanmun Hundok (漢文訓讀). However, he also pointed out that these have been often transmitted with original Hanmun (漢文) texts together.

In addition, there have been a few mentions that Ŏnhaemun (諺解文) of Ŏnhae (諺解) materials “corresponds to Japanese Kanbun Yomikudashibun (漢文読下し文)” (Kanno [菅野 裕臣], 1996, p. 108), “has a similar characteristics with Kakikudashibun (書き下し文)” (O [ 呉美寧], 2004, p. 33), and so forth. However, we can not find the researches to reconstruct the systems of Hanmun Hundok (漢文訓讀) in these days from such perspectives.

8 Tsukishima [築島 裕] (1963:101-102) gave the five materials to research the language use reality and situation of Hanmun Hundok (漢文訓讀) in Heian-era (平安時代).

Kunten (訓点) materials.

Kakikudashibun (書下し文), the results of Hanmun Hundok (漢文訓讀).

The sentences that would be written in the order of Hanmun Hundok (漢文訓讀), even though original Hanmun (漢文) texts are unknown. The kinds of Wakan Konkobun (和漢混 淆文) in a broad sens, the sentence written in a mixture of Japanese and Chinese.

The kinds of Ongi (音義), dictionary.

The materials to show the social background of Hundok (訓読).

Of these, he pointed out, that there are various materials of (2) Kakikudashibun (書下し文), the results of Hanmun Hundok (漢文訓讀), such as Kanagaki Hokekyo (仮名書法華経), Bussetsu Amidakyo (仏説阿弥陀経), Kan Muryojukyo (観無量寿経), Kanagaki Rongo (か ながきろんご) (These are Hiragana (平仮名) books), and Shakanyorai Nenjuno Shidai (釈 迦如来念誦之次第 (This is Katakana(片仮名) book owned by Tenri Library (天理図書館)), and so forth, and that "we can use these materials usefully if only the way of the usage is valid." (p. 102)

It seems that Ŏnhaemun (諺解文) in Korea nearly corresponds to (2) materials, and so, these would be valuable materials to research the systems of Hanmun Hundok (漢文訓讀) in these days. 


\section{The relation of Sŏktok Kugyŏl materials and Ŏnhae materials}

This chapter will deal some examples, and we will discuss some advantages and points. In this paper, incidentally, Onhae (諺解) materials of the 15th century, such as Nŭngŏmgyŏng Ŏnhae (楞嚴經諺解)[1462], Pŏphwagyŏng Ŏnhae (法華經諺解) [1463], Naehun (内訓)[1475], Tusi Ornhae (杜詩諺解) [1481], and so forth, will be treated as main sources. We will refer to Hancha (漢字) dictionaries published in the 16 th century or other materials when necessary.

\section{1 '況'}

“況” is written as “廣韻云，「鴙也。」愚案義轉而益進，則云況也。” in Zhùzì Biànlue (助字辨略). And “As “況” is originally 匹擬也 (Guăngyùn(廣韻)), the sentences including '況' have the structure that is comparing the sentence above with the sentence below” (Kasuga [春日政治], 1938/1984, p. 346). It is also said that “況” in auxiliary word usage, is used as conjunction (連詞) or adverb.9

The examples of Sŏktok Kugyŏl (釋讀口訣) materials are as follows.

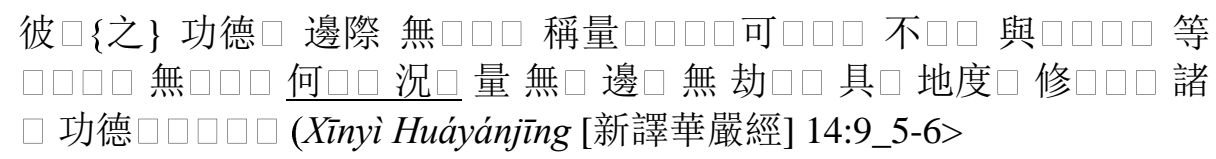

(1) is marked '況 $\square$ '. It seems to transcribe ' $\square \square$ 며' in the 15th century, because ' $\square$ ' is probably Marŭm Ch'ŏmgi (末音添記) of Hun (訓) of character '況'. In this example, the other hand, original Hanmun (漢文) text is '何況”, and Kugyŏl (口訣) marking there is '何 $\square \square$ 況 $\square$ '. There are various theories about the reading '何 $\square \square$ ', but that correspond to '엇 뎨 $\square \square$ 며' of the 15th century, in any way.10

In Ŏnhae (諺解) materials from the 15th century, it is common read as adverb ‘ • - 며' among the materials, except verbal reading '가 - 비다'.
a. 當知虚空이 生汝心内호미 猶如片雲이 點太清裏 $\square$ 니 況諸世界 1 在虚空耶 $1 \square$ 녀
b. 반 $\square$ 기 알라 虚空이 네 $\square \square$ 안해 나미 片雲이 大清 안해 點혼 $\square \square$ 니 $\square \square$ 며 한 世界 虚空애 이쇼미 $\square$ 녀 (Nŭngŏmgyŏng Ŏnhae [楞嚴經諺解] 9:44a-44b_本)

\footnotetext{
9 However, it is difficult to distinguish between these two. In addition, Kasuga [春日政治] (1938/1984) called ‘イハムヤ', of Japanese Kanbun Kundoku (漢文訓読) materials, 'conjunctive adverb (接続的副詞)'.

${ }^{10}$ However, ‘何況' in original Hanmun(漢文) texts was not always read as '엇 뎨 $\square \square$ 며', but there are a lot of examples to be read as ' $\square \square$ 며' alone. See (5) (6). Incidentally, ‘何況' was written as ‘用反問的語氣表達更進一層的意思。’ in Hànyǔ Dàcídiăn (漢語大詞典).
} 
（3）ａ．炎宵惡明燭 況乃懷舊丘

b. 더운 바 $\square \square \square$ 燭스 브를 아쳗노니 $\square \square$ 며 넷 $\square \square \square \square$ 호미 $\square$ 녀 (Tusi Onhae [杜詩諺解] 10:21b)

(4) a. 至於犬馬 $\square$ 야도 盡然이어니 而況於人乎

b. 가히 $\square \square$ 게 니르러도 다 그리 홀디어니 $\square \square$ 며 사 $\square$ 미 $\square$ 녀 (Naehun [内訓] 1:44b)

a. 若是施主 $\mid$ 但施衆生의게 一切樂具 $\square$ 야도 功德이 無量커 $\square$ 何沉令得阿羅漢果 $1 \square$ 니 $\square$ 가

b. $\square$ 다가 이 施主 I 오직 衆生의게 一切 즐거운 거슬 주어도 功德이 그지업거늘 $\square \square$ 며 阿羅漢果 $\square$ 得게 호미 $\square$ 니 $\square$ 가 (Pŏphwagyŏng Ŏnhae [法華經諺解] 6:9a_本)

(6) a. 舎利弗아 十方世界中에 尚無二乘커니 何況有三이리오

b. 舎利弗아 十方世界中에 오히려 두 乘이 업거니 엇뎨 $\square \square$ 며 세히 이시리오 (Pöphwagyŏng Ǒnhae [法華經諺解] 1:186b_本)

‘況' did not exist in Hancha (漢字) dictionaries of the 16th century, but ' $\square \square$ 며' is common in Sŏktok Kugyŏl (釋讀口訣) materials in Koryŏ-era (高麗時代) and Ŏnhae (颜解) materials of the 15th century. Accordingly, it seems that ' $\square \square$ 며' had been fixed as Hun (訓) of character ‘況”.

\section{2 '當”}

“當” have two kinds of tones, even tone (平声) and going tone (去声), but we will treat even tone (平声) here. Two kinds also appear in Zhùzì Biànlue (助字辨略), but there are a lot of mentions, such as “應也, 合也”, “語助, 猶云將也”, “猶云方也”, and so forth, for even tone (平声), while only one mention “當日, 即日也” for going tone (去声).

In Sǒktok Kugyŏl (釋讀口訣) materials, ‘當’ is marked ‘ $\square$ ’ without exception.

(1) 大王 $\square$ 當 $\square$ 知 $\square \square \square \square$ (Xīnyì Huáyánjīngshū [新譯華嚴經䟽] 35:10_17-18)

(2) 廣 $\square$ 説 $\square \square \square$ 當 $\square$ 知 $\square \square$ 二十種 有 $\square \square \square$ 菩薩地 $\square \square$ 當 $\square$ 説 $\square \square \square$ 如 (Yúqiéshīdilùn [瑜伽師地論] 20:4_9-10)

(3) 今 $\square \square$ 我 $\square$ 亦 $\square \square$ 當 $\square$ \{於\}往昔 $\square \square$ 同 $\square \square \square$ 而 $\square$ 其 命 $\square$ 捨 $\square \square \square \square \square \square$ (Xìnyì Huáyánjīngshū [新譯華嚴經䟽] 35:10_10-11>)

(4) 謂 $\square$ 我 $\square$ 當 $\square$ \{於\}无戯論涅槃 $\square \square$ 心 $\square \square$ 退轉 $\square \square$ 无 $\square$ (Yúqiéshìdilùn [瑜 伽師地論] 20:8_17-18>

In these examples, '當' was treated as adverb, and marking ' $\square$ ' was probably Marŭm Ch'ómgi (末音添記) of Hun (訓) of character “當”. Thus it seems to transcribe '반 $\square$ 기' or '반 $\square$ '. 
In Ónhae (諺解) materials of the 15th century, most of “當” characters are also read as '반 $\square$ 기', except verbal reading ‘當 $\square$ 다'.

(5) a. 如是等人이 $\square$ 則能信解 $\square$ 리니 汝當爲説 妙法華經 $\square$ 라

b. 이러 $\square \square$ 사 $\square$ 미 $\square$ 能히 信解 $\square$ 리니 네 반 $\square$ 기 妙法華經을 爲 $\square$ 야 니 $\square$ 라 (Pŏphwagyŏng Ŏnhae [法華經諺解] 2:173b_本)

(6) a. 阿難이 白佛言호 $\square$ 世尊하 當於結心에 解 $\square$ 면 即分散 $\square$ 리 $\square$ 다

b. 阿難이 부텨 $\square \square$ 오 $\square$ 世尊하 반 $\square$ 기 $\square$ 가온 $\square$ 그르면 곧 갈아디리 $\square$ 다 (Nŭngŏmgyŏng Ŏnhae [楞嚴經諺解] 5:24b_本)

(7) a. 人이 無父母 I I 어든 生日에 當倍悲痛이니 更安忍置酒張樂 $\square$ 야 以爲樂이리오

b. 사 $\square$ 미 父母 $\mid$ 업거든 난 나래 반 $\square$ 기 倍히 슬허 홀디니 가 $\square$ 야 엇디 술 버리고 音樂 $\square$ 야 $\square$ 즐교 $\square \square$ 리오 (Naehun [内訓] 1:58b)

(8) a. 明明領處分一一當剖析

b. $\square$ 기 기걸호 $\square$ 아라셔 一一히 반 $\square$ 기 剖析호라 (Tusi Ǒnhae [杜詩諺解] $17: 14 \mathrm{a})^{11}$

Furthermore, the examples of Hancha (漢字) dictionaries in the 16th century are as follows.

(9) 當 반 $\square$ 당 (Kwangju Ch'ŏnjamun [光州千字文] 11b)

(10) 반 $\square$ 당 當 (Paengnyŏn Ch'ohae [百聯抄解] 12b)

(11) 반 $\square$ 당 當 (Paengnyŏn Ch'ohae [百聯抄解] 13b)

(12) 當 맛당 당 又平聲 (Sinjŭng Yuhap [新增類合] 下:9b) ${ }^{12}$

(13) 當 맛 $\square$ 당 (Sŏkpong Ch’ŏnjamun [石峯千字文] 11b)

There are two different kinds of Hun (訓), one is '반 $\square$ ' as (9) (11), and the other is

11 Incidentally, it is well known that, in Tusi Ŏnhae (杜詩諺解), not only '반 $\square$ 기' as adverb but also '반 $\square$ 시', the ' $\neg \sim$ 入' changed form, appears for the first time, and actually, four examples were found. However, all of those are the examples of '必' character's reading such as follows, so that there were no example of “當” character's reading.

(1) a. 負米晚爲身毎食臉必泫

b. $\square$ 쥬믈 늘거셔 모 $\square$ 爲 $\square$ 니 $\square \square$ 밥 머글 제 $\square \square$ 반 $\square$ 시 $\square$ 므를 흘리더라 (Tusi Ŏnhae [杜詩諺解] 24:32a)

(2) a. 文彩承殊渥流傳必絶倫

b. 빗 $\square$ 조로 님 $\square$ 殊異 $\square$ 恩渥 $\square$ 닙 $\square$ 오니 流傳 $\square$ 야 가 $\square$ 반 $\square$ 시 等倫 에 그츠리로다 (Tusi Ŏnhae [杜詩諺解] 16:5a-5b)

12 In this example, a circle(圏點) is added to the upper right hand side of “當” character, meaning the character going tone(去声), and it is written as '又平聲' under the Hun(訓) '맛당 당'. 
‘맛당(맛 $\square$ )' as (12) (13). In there, '반 $\square$ ' appears in Kwangju Ch'ŏnjamun (光州千字 文) which is said to have included the old Hun (古訓) especially, and it is the common to Ŏnhae (諺解) materials of the 15th century and Sŏktok Kugyŏl (釋讀口訣) materials.

Thus, it seems to have some difficulties, but at least, '반 $\square$ 기(반 $\square$ )' had been fixed as Hun (訓) of character '當”, until the end of the 15 th century.

\section{3 '亦'}

In Zhùzi Biànlue (助字辨略), “亦” is written as “總也” quoted from Guăngyùn (廣 韻). And “亦' of auxiliary word usage, is used as adverb in general, as with several meanings such as “(1)也; 也是。(2)又。(3)尚; 猶。(4)已; 已經。(5)僅僅; 只是。 (6)皆。” in Hànyǔ Dàcídiǎn (漢語大詞典). ${ }^{13}$

In Sŏktok Kugyŏl (釋讀口訣) materials, there were two kinds of Kugyŏl (口訣) markings in character ‘亦'.

(1) 衆生 $\square$ 形相 $\square$ 各 $\square$ 不 $\square$ 同 $\square \square$ 行業 $\square$ 音聲 $\square \square$ 亦 $\square$ 量 $\square$ 無 $\square \square$ (Xinyi Huáyánjīng [新譯華嚴經] 14:15_1)

(2) 減 $\square \square$ 無 $\square$ 增 $\square \square$ 無 $\square$ 亦 $\square \square$ 盡 $\square$ 無 $\square$ 如 $\square$ 菩薩 $\square$ 功德聚 亦 $\square$ 然 $\square \square \square \square$ (Xīnyì Huáyánjīng [新譯華嚴經] 14:14_14)

(1) is marked ' $\square$ '. Nam [南豊鉉] (2007) treated it with Chŏnhuncha(全訓字) of particle '-도', but it is also possible to treat with Marŭm Ch’ŏmgi(末音添記) of adverb ‘ $\square$ '. Example (2), ‘亦' of the earlier part, was marked ‘ $\square \square$ ', and it seems that ‘亦 $\square \square$ ' was read as ' $\square \square$ '. In any way. there is no doubt that ' $\square$ ' had been considered Hun(訓) of character ‘亦'.

The examples of Ŏnhae (諺解) materials in the 15th century are as follows.

a. 諸菩薩衆이 亦得是三昧와 及陀羅尼 $\square$ 시니라

b. 諸菩薩衆이 $\square$ 이 三昧와 陀羅尼 $\square$ 得 $\square$ 시니라 (Pöphwagyŏng Ŏnhae [法華經諺解] 6:184a_解)

(4) a. 佛亦如是 $\square$ 야 出現於世호미 譬如大雲이 普覆一切 $\square \square$ 니라

b. 부텨도 이 $\square \square$ 야世間애 나 現호미 가 $\square$ 비건댄 큰 구루미 一切예 너비 둡 $\square \square$ 니라 (Pŏphwagyŏng Ŏnhae [法華經諺解] 3:37b-38a_本)

(5) a. 我等도亦佛子 $\mid$ 라

b. 우리도 $\square$ 佛子 I 라 (Pŏphwagyŏng Ŏnhae [法華經諺解] 2:11b_本)

${ }^{13}$ However, in Hànyǔ Dàcídiăn(漢語大詞典), character ‘亦’ in auxiliary word usage was written as ‘連詞。假如, 如果。’, ‘助詞, 無義。', besides the various meanings of adverb. 
(3) (4) were read as adverb ' $\square$ ' and particle '-도' each other. And in (5), both two forms were read in concord as '-도 $\square$ ', which is similar to 'Momata (モ亦)' of Japanese Kanbun Kundoku (漢文訓読).14 However, it is more often to be read as only adverb ' $\square$ ' such as (3) without particle '-도'.

The examples of Hancha (漢字) dictionaries in the 16th century are as follows.

(6) 亦 $\square$ 역 (Kwangju Ch’ŏnjamun [光州千字文] 21a)

(7) 亦 $\square$ 역 (Sǒkpong Ch’ŏnjamun [石峯千字文] 21a)

(8) 亦 도 역 (Sinjŭng Yuhap [新增類合] 上:14b)

Example (8), of Sinjŭng Yuhap (新增類合), is written as '도 역', and so, particle '-도' might be treated as Hun (訓) of character ‘亦', unless it is misspelling. Otherwise, adverb ' $\square$ ' is treated as Hun (訓) of it. Anyway, there is no doubt that Hun (訓) of character ‘亦’ was primarily adverb ‘. ’.

Thus, ‘亦' is also the example that the reading method was common to Sŏktok Kugyŏl (釋讀口訣) materials, Ŏnhae (諺解) materials, and Hancha (漢字) dictionaries in the 16 th century.

The above three characters are that the reading method was common to Sŏktok Kugyŏl (釋讀口訣) materials, Ŏnhae (諺解) materials, and Hancha (漢字) dictionaries in the 16th century.['況' as ' $\square \square$ 며', ‘當' as '반 $\square$ 기(반 $\square$ )', and ‘亦' as ‘ $\square$ '.] Therefore, we can verify that Hun (訓) of these characters had been fixed and persisted.

In other words, these are good examples that we can research how to read Sŏktok Kugyŏl (釋讀口訣) materials based on Ŏnhae (諺解) system of Hanmun (漢文) texts in these Ŏnhae (諺解) materials.

However, we have to pay attention to the situations that the persistences mentioned above are not always verified with all characters. Below are the examples.

\section{4 '與'}

'與' have some kinds of tones. Even tone (平声) is used to the end of a sentence in auxiliary word usage, that means a question, a rhetorical question, or an exclamation. However, we will treat rising tone (上声) here. Auxiliary word '與' as rising tone (上声) can be largely divided into two types, preposition (介詞) or conjunction (連詞). The meaning of “與' is similar to ‘亦' or '及', and in Zhùzì Biànlue (助字辨略), “與” is written as “與, 及也” quoted from Lùnyǔ (論語).

${ }^{14}$ See Kasuga [春日政治] (1942/1985, p. 279). 
The examples of Sŏktok Kugyŏl (釋讀口訣) materials are as follows.

（1）唯 $\square$ 佛 $\square$ 與 $\square$ 佛 $\square \square \square \square$ 乃 $\square$ \{斯\} $\square$ 事 $\square$ 知 $\square \square \square \square$ (Jiùyi Rénwángjīng [舊 譯仁王經] 上:11_24)

In (1), ‘與' was read as adverb, and ‘ $\square$ ' was probably Marŭm Ch’ŏmgi (末音添 記) of the word. Thus, it seems to transcribe '다 $\square$ ' of Chŏngŭm (正音) materials in later ages.

In Ŏnhae (諺解) materials, on the other hand, the reading method of character '與' shows different trend by each materials.

(2) a. 此諸物象과 與此見精이 元是何物이완

b. 이 모 $\square$ 物象과 이 見精이 本來 이 엇던 物이완 $\square$ ((Nŭngŏmgyŏng Ŏnhae [楞嚴經諺解] 2:56a-56b_本)

(3) a. 爾時예 釋提桓因이 與其眷屬二萬天子와 俱 $\square$ 며

b. 그 $\square$ 釋提桓因이 粗屬二萬天子와 $\square \square$ 와시며 (Pŏphwagyŏng Ŏnhae [法華經諺解] 1:45a_本)

(4) a. 及退 $\square$ 야 而自婇栝日之所行과 與凡所言 $\square$ 니

b. 믈러나 날로 行홀 바와 다 $\square$ 믈읫 닐온 바 $\square$ 檼栝 $\square$ 야 보니 (Naehun [内訓] 1:16b)

(5) a. 可憐忠與孝 兩美畫麒麟

b. 可히 $\square$ 온 忠과 다 $\square$ 孝 $\square$ 두 아 $\square$ 다오 $\square$ 麒麟閣애 그리리로다 (Tusi Ónhae [杜詩諺解] 24:4b)

(2) (3) were read as particle '-와/과', but (2) was read as connective particle, and (3) as adverbial particle. Most of '與' characters were read as particle '-와/과' in the Buddhist $\breve{O n h a e}$ (諺解) materials in the mid-15th century.

Meanwhile, (4) (5) were read as adverb ‘다 $\square$ ', like (1) of Sŏktok Kugyŏl (釋讀口 訣) materials. The word '다 $\square$ ' as the reading of '與' increases rapidly since the end of the 15th century, more precisely, since Naehun (内訓)[1475], Tusi Ónhae (杜詩諺解) [1481].

The examples of Hancha (漢字) dictionaries in the 16th century are as follows.

(6) 與 다 $\square$ 여 (Kwangju Ch’ŏnjamun [光州千字文] 11a)

(7) 與 다 $\square$ 여 (Sinjǔng Yuhap [新增類合] 下:63a)

(8) 與 더블 여 (Sǒkpong Ch’ŏnjamun [石峯千字文] 11a) 
(6) (7) were written adverb '다 $\square$ ', that is common to '與 $\square$ ' of Sŏktok Kugyŏl (釋 讀口訣) materials or Naehun (内訓)[1475], Tusi Ŏnhae (杜詩諺解), except verb '더블다' such as (8) of Sŏkpong Ch’ŏnjamun (石峯千字文).

Thus, character '與' was read as particle '-와/과' in Ŏnhae (諺解) materials in the mid-15th century. However around the period adverb '다 $\square$ ' had been fixed as Hun (訓 ) of the character firmly. Furthermore, '다 $\square$ ' itself is not appear at all in the Chŏngŭm (正音) materials since the mid-15th century, the promulgation of Hunmin Chyŏngŭm (訓民正音), to Naehun (内訓)[1475].

\section{5 '及'}

'及' is used as verb that means 'reach, arrive', and in auxiliary word usage, it is used as preposition (介詞) or conjunction (連詞). It seems that the former is written as '至也, 逮也', and the latter as “連及之辭也’ in Zhùzì Biànlue (助字辨略), quoted from Guăngyùn (廣韻).

However, we will treat only conjunction (連詞) usage here, because it is difficult to distinguish between verbal usage and preposition (介詞) usage.15

The examples of Sŏktok Kugyŏl (釋讀口訣) materials are as follows.

（1）謂 $\square$ 有餘依涅槃界 $\square$ 及 $\square$ 無餘依涅槃界 $\square \square$ 依止 $\square \square \square \square$ (Yúqiéshìdilùn [瑜伽師地論] 20:4_20-21)

(2) 五欲 $\square$ 及 $\square$ 王位 $\square$ 富饒 $\square$ 自樂 $\square$ 大名稱 $\square \square \square \square$ 求 $\square \square \square \square \square \square$ 不 $\square \square$ (Xīnyì Huáyánjīng [新譯華嚴經] 14:9_12)

（3） 佛 $\square$ 及 $\square$ 衆生 $\square \square \square \square 一 \square \square$ 而 $\square$ 二 無 $\square \square \square$ (Jiùyì Rénwángjīng [舊譯仁 王經] 上:15_12)

（4）五者一切 諸佛 $\square$ 不共法 等 $\square \square \square \square$ 及 $\square$ 一切 智智 $\square \square \square \square$ 灌頂智 能 具足 (Hébù Jinnguāngmingjīng [合部金光明經] 3:5_6-7)

These examples show different trend by each materials. That is, one is marked ' $\square$ ' such as (1) (2) of Yúqiéshīdilùn (瑜伽師地論) and Xīnyì Huáyánjīng (新譯華嚴經), and the other is marked ' $\square$ ' such as (3) (4) of Jiùyì Rénwángjīng (舊譯仁王經) and

15 For example, example (1) can be judged as verbal usage, however, example (2) is difficult to judge whether it is verbal usage or preposition (介詞) usage.

(1) a. 相及 $\square$ 야 $\square$ 乃有畔 $\square \square$ 니 畔義不成 $\square$ 니 非非和也 I 로다

b. 서르 미처 $\square \square$ 잇 $\square$ 니 $\square \square$ 디 이디 아니 $\square$ 니 아니 和혼 디 아니로다

(Nŭngŏmgyŏng Ŏnhae [楞嚴經諺解] 2:102b_解)

a. 從其室門 $\square$ 야 後及庭際 $\square$ 리니

b. 그 집 門 $\square$ 조차 後에 $\square \square \square$ 미츠리니 (Nŭngŏmgyŏng Ŏnhae [楞嚴經諺解] 1:53a_本) 
Hébù Jīnguāngmíngjīng (合部金光明經). The reading method of the latter examples is unknown, but the former examples marked ' $\square$ ' are probably Marŭm Ch'ŏmgi (末音添 記) of character '及'. Thus, it seems to transcribe adverb ‘밋', Hun (訓) of character ‘ 及'。

In Ŏnhae (諺解) materials, it is also extremely complicated.

a. 諸天龍夜叉와 及阿修羅等이 皆以恭敬心으로 而共來聽法 $\square$ 리니

b. 諸天龍夜叉와 $\square$ 阿修羅 $\square$ 히 다 恭敬 $\square \square \square$ 로 모다 와 法 드르리니 (Pŏphwagyŏng Ŏnhae [法華經諺解] 6:56a_本)

(6) a. 若本戒師 $)$ 어나 及同會中에 二不清淨 $\square$ 면 如是道場이 終不成就라 $\square$ 시니라

b. $\square$ 다가 믿 戒師 1 어나 $\square \square$ 會中에 $\square$ 나히나 清淨 몯 $\square$ 면 이 $\square$ 티 道場이 내 $\square$ 내 이디 몯 $\square \square$ 니라 $\square$ 시니라 (Pŏphwagyŏng Ŏnhae [法華經諺解] 7:173a_解)

(7) a. 身心이 滅盡者 $\square$ 無色蘊과 及鹿識也 「라

b. 身心이 滅 $\square$ 야 다오 $\square$ 色藴과 鹿 $\square$ 識이 업수미라 ((Nŭngŏmgyŏng Ŏnhae [楞嚴經諺解] 9:32a_解)

(8) a. 阿難아 若此比丘의 本受戒師 | 어나 及同會中十比丘等이 其中에 有一不清淨者 | 면 如是道場이 多不成就 $\square$ 리라

b. 阿難아 $\square$ 다가 이 比丘의 本來 受戒 $\square$ 스스 $\square$ 어나 同會中엣 열 比丘 $\square$ 히 그 中에 $\square$ 나히나 清淨티 아니 $\square$ 니 이시면 이 $\square$ 티 道場이 해 이디 몯 $\square$ 리라 (Nŭngŏmgyŏng Ŏnhae [楞嚴經諺解] 7:25a_本)

In (5) (6), '及' was read as adverb ' $\square$ ' which is in concord with the preceding auxiliary word such as particle '-와/과', conjunctive ending '-거나', and so forth. However, in (7) (8) were read as only these auxiliary word without adverb ' $\square$ ' appearing. In Nŭngŏmgyŏng Ŏnhae (楞嚴經諺解), there are many examples to read ‘ 及' as both adverb ' $\square$ ' and the auxiliary words equally, while in Pŏphwagyŏng Ŏnhae (法華經諺解), most of examples are read as these auxiliary words alone, except only one exception that is read as adverb ' $\square$ '. This suggests that there are differences of Ŏnhae (諺解) system between Nŭngŏmgyŏng Ŏnhae (楞嚴經諺解) and Pŏphwagyŏng Ŏnhae (法華經諺解). 16

\footnotetext{
${ }^{16}$ As for the details of completing Ŏnhae (彥解) of each materials, in Nŭngŏmgyŏng Ŏnhae (楞 嚴經諺解), there are some descriptions in the afterword (跋文) that King Sejo (世祖) marked Kugyŏl (口訣) directly at first, and after that Kim Suon (金守温) and Han Kyehŭi (韓繼禧) translated. However, in Pŏphwagyŏng Ŏnhae (法華經諺解), there are no description as described above, so that it is estimated from several situations, that the same persons would have involved in compiling the materials (An [安秉禧], 1998/2009a, pp. 68-69), etc.). And this has been generally accepted. But considering to the subtle difference of Ŏnhae (諺解) system between two materials mentioned above, it might be necessary to re-consider the estimate of the persons compiling Pŏphwagyŏng Ŏnhae (法華經諺解) more carefully.
} 
a. 又如舊擧將과 及嘗爲舊任按察官者를 後에 己官이 雖在上이나 前輩 \皆辭避 $\square$ 야 坐下坐 $\square$ 더니

b. $\square$ 녜 쳔거 $\square$ 던 사 $\square$ 과 밋 일즉 녜 검찰 $\square \square$ 벼슬 $\square$ 엿던 관원을 후에 내 벼슬이 비록 우 $\square$ 이시나 넷 사 $\square$ 미 다 $\square \square \square$ 며 피 $\square$ 야 아래 좌애 안 $\square$ 니 (Pŏnyŏk Sohak [翻譯小學] 7:46b-47a)

(10) a. 慶及諸子। 入里門 $\square$ 야 趨至家 $\square$ 더라

b. 慶과 밋 모 $\square$ 아 $\square$ 이 ⿻日土門의 들어 $\square$ 조 걸어 집의 닐으더라 (Sohak Onhae [小學諺解] 6:80b)

(9) (10), on the other hand, are examples of Pŏnyŏk Sohak (翻譯小學) [1518] and Sohak Onhae (小學諺解) [1588]. These are read as '밋', that is common to Sóktok Kugyŏl (釋讀口訣) materials. The word '밋' itself is very few in the 15th century, but in the 16th century, it increase significantly as reading '及' character. In this respect, it is similar to '與' character above.

The examples of Hancha (漢字) dictionaries in the 16th century are as follows.

(11) 及 밋 급 (Kwangju Ch’ónjamun [光州千字文] 7a)

(12) 及 미 $\square$ 급 (Sǒkpong Ch'ónjamun [石峯千字文] 7a)

(13) 及 미츨 급 (Sinjüng Yuhap [新增類合] 下:42a)

(11) of Kwangju Ch'ónjamun (光州千字文), was written '밋', that is common to Sóktok Kugyŏl (釋讀口訣) materials or Ŏnhae (諺解) materials in the 16th century such as (9) (10). In other respects, (12) of Sökpong Ch'ónjamun (石峯千字文), and (13) of Sinjüng Yuhap (新增類合), was written as verb '및다'.

As shown above, reading method of character '及' was extremely complicated. There are examples to be read as adverb '밋' in Sŏktok Kugyŏl (釋讀口訣) materials, Onhae (諺解) materials in the 16th century, and Hancha (漢字) dictionaries in the 16th century, so that, it seems that '밋' had been fixed as Hun (訓) of character '及'. However, of Onhae (諺解) materials in the mid-15th century, it was read as adverb ' • ' or auxiliary word such as particle '-와/과', conjunctive ending '-거나', and so forth. Not only that, the word '밋' itself is very few in the 15 th century. ${ }^{17}$

As discussed above, there is a similarity between '與' and '及' each other. That is, the reading methods of these characters are common between Sŏktok Kugyŏl (釋讀口 訣) materials and Ŏnhae (諺解) materials since the end of 15th century or the 16th

${ }^{17}$ Incidentally, the word '밋' as adverb is very few in the 15 th century, however, the same form in verbal usage '및다' appears frequently, and it had also been used as the reading of character '及' in verbal usage. Then, we may not be able to assert that '밋' have disappeared at all in the 15 th century. 
century[與 as 다 $\square$, and '及' as '밋'.]. While the other reading method existed in Ŏnhae (諺解) materials in the mid-15th century.

It is not easy to provide an explanation for this, but one thing that we would like to stress that, most of materials in the mid-15th century were Buddhist materials, while Non-Buddhist (Confucian) materials had increased since the end of 15 th century. In other words, variations in language use, in more detail, the variations in Hanmun Hundok (漢文訓讀) traditions among Buddhist and Non-Buddhist group, appeared in different periods. 18

From the above, we will reach a strange conclusion, that the tradition of Hanmun Hundok (漢文訓讀) in Sŏktok Kugyŏl (釋讀口訣) materials had been succeeded to Non-Buddhist(Confucian) group, and another tradition had existed separately among Buddhist group in the mid-15th century. Or it might be better to consider that the tradition of Hanmun Hundok (漢文訓讀) in Korea was basically consistent. However, the tradition among Buddhist group in the mid-15th century were quite peculiar.

Certainly, there are also examples such as ‘況”, “當”, ‘亦”, mentioned above, that the reading methods are common to Buddhist Ŏnhae (諺解) materials in the mid-15th century. However we cannot overlook the fact that the reading methods of these characters were common among Buddhist Ŏnhae (諺解) materials and Non-Buddhist (Confucian) Ŏnhae (諺解) materials. Moreover, from a preliminary study, it seems that there are more examples such as '與' or “及'.19 I would like to continue considering these examples.

In any case, it should be stressed that Non-Buddhist (Confucian) Ŏnhae (諺解) materials occupy an important position to consider the reading methods of Sóktok Kugyŏl (釋讀口訣) materials.

\footnotetext{
${ }^{18}$ For the various forms in the materials written in different days, there is a research such as Ch'oe [崔明玉] (2002) treating past tense suffix formation. He did not regard these forms as the historical chronically successive, but payed attention to the characteristics of the materials, and concluded that these distinct forms have been used in different regional and social dialects, and have been reflected in written text separately. However, there are few detailed research on his argument, that language use among the groups (Buddhist and Non-Buddhist group) had been different each other, except a verbal evidence by Kwŏn Odon (權五惊)[A Chinese scholar, 1901 1984] that language use were different for each alley in P'alp'an-dong (八判洞), Chongno-gu (鐘路區), Seoul, in the early 1940s. It seems that there is a gap in his argument, however, for future research about the history of Korean language, such viewpoints might be necessary, in any case.

${ }^{19}$ For example, ‘各 $\square \square$, 各 $\square \square$, 各 $\square \square \square$ '(제여곰, 제곰), ‘更 $\square$ '(가 $\square$ 야, 가 $\square$ 여), ‘共 $\square$ '(다 $\square$ ), $\lceil$ 并 $\square\rfloor$ (아오로), and so forth.
} 


\section{Closing Remarks}

As stated above, we have discussed some of the advantages and points of the attempt to research how to read Sŏktok Kugyŏl (釋讀口訣) materials based on Ŏnhae (諺解) materials, with each examples. As a result, Hundok (訓讀) systems of Sóktok Kugyŏl (釋讀口訣) materials had much resemblance to the Non-Buddhist (Confucian) Onhae (諺解) materials since the end of 15 th century.

Recently, as studies of Sŏktok Kugyŏl (釋讀口訣) materials advanced, it has been often pointed out that it is important to classify the group of the materials, such as Huáyánjīng (華嚴經) group, Yúqiéshīdilùn (瑜伽師地論) group, and so forth. Furthermore, these classifications have been positively applied to the deciphering of Cypher (角筆) materials.

However, as for the groups, it seems that the relation with Ŏnhae (諺解) materials should be also considered. In that respect, it seems that Sŏktok Kugyŏl (釋讀 口訣) materials and Non-Buddhist (Confucian) Ŏnhae (諺解) materials have deep connection. In future study, various examples should be treated in detail. This paper, which treated a few examples, is nothing more than a preface of the future research.

\section{Note}

This work was supported by JSPS KAKENHI Grant Number 25770145. An earlier version of this paper was presented at the 2nd Korean International Symposium of the Department of Asia and African Studies, Faculty of Arts, University of Ljubljana "Understanding Chinese Characters and Cultures in East Asia" in June 2014.

\section{References}

An, P. [安秉禧] (1973). Chungse kugŏ yŏn'gu charyoŭi sŏngkyŏge taehan yŏn'gu -Pŏnyŏk yangsigŭl chungsimŭro hayŏ- [中世國語 研究 資料手 性格에 대한 研究-㼑譯樣式을 중심으로 하여-]. Ŏhak yŏn'gu [語學研究], $I X-1$. Sŏul taehakkyo Ŏhak Yŏn'guso [서울 大學校 語學研究所]. In An, P. [安秉禧] (1992b, pp. 11-27).

An, P. [安秉禧] (1976). Kugyŏlgwa hanmun hundoge taehayŏ [ᄆ訣과 漢文訓讀에 대하여]. Chindan hakpo [震檀學報], 41. Chindan Hakhoe [震檀學會]. In An, P. [安秉禧] (1992a, pp. 287-313).

An, P. [安秉禧] (1984). Han'gugŏ ch'acha p'yogipŏbŭi hyŏngsŏnggwa t’ŭkching [韓國語 借

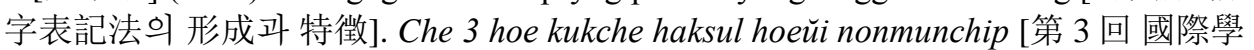
術會議 論文集]. Sŏngnam: Han'guk Chŏngsin Munhwa Yŏn'guwŏn [韓國精神文化研究 院]. In An, P. [安秉禧] (1992a, pp. 269-286).

An, P. [安秉禧] (1985). Ŏnhaeŭi sachŏk koch'al [諺解手 史的 考察]. Minjok munhwa [民族文 化], 11. Minjok Munhwa Ch'ujinhoe [民族文化推進會]. In An, P. [安秉禧] (2009a, pp. 11-23). 
An, P. [安秉禧] (1987). Kyunyŏŭi pangŏnbon chŏsure taehayŏ [均如의 方言本 著述에 대하여]. Kugŏhak [國語學], 16. kugŏ Hakhoe [國語學會]. In An, P. [安秉禧] (1992a, pp. 314-327).

An, P. [安秉禧] (1992a). Kugǒsa yŏn'gu [國語史 研究]. Seoul: Munhakkwa Chisŏngsa [文學 과 知性社].

An, P. [安秉禧] (1992b). Kugǒsa charyo yŏn'gu [國語史 資料 研究]. Seoul: Munhakkwa Chisŏngsa [文學과 知性社].

An, P. [安秉禧] (1997). Hwalchabon Nŭngŏmgyŏng Ŏnhae haeje -kwŏn $1 \cdot 10$ ŭl chungsimŭro- [活字本 楞嚴經諺解 解題 - 권 1・10 을 중심으로]. In Yŏnginbon Taebulchŏng Yŏrae Mirin Sujŭng Yoŭi Chebosal Manhaeng Sunŭngŏmgyŏng pyŏlch'aek [ 影印本 大佛頂如來密因修證了義諸菩薩萬行首楞嚴經 別冊]. Seoul: Munhwajae Kwalliguk 文化財管理局]. In An, P. [安秉禧] (2009a, pp. 271-301).

An, P. [安秉禧] (1998). Kan'gyŏngdogamŭi ŏnhaebone taehan yŏn'gu [刊經都監의 諺解本에 대한 研究]. In Wŏrun sŭnim kogi kinyŏm nonch'ong kanhaeng wiwŏnhoe [月雲스님 古 稀記念 論叢 刊行委員會] (Ed.), Wǒrun sŭnim kogi kinyŏm pulgyohak nonch'ong [月雲 스님 古稀記念 佛敎學論叢]. Seoul: Tongguk Yŏkkyŏngwŏn [東國譯經院]. In An, P. [安 秉禧] (2009a, pp. 66-93).

An, P. [安秉禧] (2001a). Sŏlch’onggwa kugŏ [설총과 국어]. Sae kugŏ saenghwal [새국어생활], 11(3). Kngnip Kugo Yŏn'guwŏn [국립국어연구원]. In An, P. [安秉禧] (2009b, pp. 13-28).

An, P. [安秉禧] (2001b). Munchasaesŏ pon Sŏlch'ongŭi wich'i [文字史에서 본 薛聰의 位置]. In Han'guk munhwawa yǒksa inmul t'amgu -Wŏnhyo • Sŏlch'ong • Iryŏn- [한국문화와 역사인물 탐구 -원효 - 설총 • 일연-]. Sŏngnam: Han'guk Chŏngsin Munhwa Yŏn'guwŏn [한국정신문화연구원]. In An, P. [安秉禧] (2009b, pp. 29-50).

An, P. [安秉禧] (2009a). Kugŏsa munhŏn yŏn'gu [國語史 文獻 研究]. Seoul: Sin'gu Munhwasa [신구문화사].

An, P. [安秉禧] (2009b). Kugó yŏn'guwa kugŏ chŏngch'aek [國語研究와 國語政策]. Seoul: Tosŏch'ulp'an Wŏrin [도서출판 월인].

Chŏng, C. [鄭濟翰] (1993). Ŏnhaemunŭi hanmun hŏsa pŏnyŏge kwanhan yŏn'gu -'Nonŏ Ŏnhae'rŭl chungsimŭro- [諺解文의 漢文 虚辭 㭛譯에 관한 研究 -<論語諺解〉를 중심으로-]. Kugŏ yŏn'gu [國語研究], 113. Sŏul Taehakkyo Taehagwŏn Kugŏ Yŏn'guhoe [서울大學校大學院 國語研究會].

Chŏng, I. [鄭寅承] (1957). Idu kiwŏnŭi chae koch'al [吏讀起源의 再考察]. In Ilsŏk Yi Hŭisŭng sŏnsaeng hwan'gap kinyŏm saŏp wiwŏnhoe [一石 李熙昇先生還甲紀念事業 委員會] (Ed.), Ilsŏk Yi Hŭisŭng sŏnsaeng songsu kinyŏm nonch'ong [一石李熙昇先生頌 壽記念論叢]. Seoul: Ilchogak [一朝閣]. In Chŏng, I. [鄭寅承] (1997, pp. 116-124).

Chŏng, I. [鄭寅承] (1997). Kŏnjae Chŏng insŭng chŏnjip 3 [건 재 정인승 전집 3]. Seoul: Tosŏch'ulp'an Pagijŏng [도서출판 박이정].

Ch'oe, H. [崔鉉培] (1961). Koch'in han'gŭlgal (Kaejŏng chŏngŭmhak) [고친 한글갈(改正 正 音學)]. Seoul: Chŏngŭmsa [정음사].

Ch'oe, M. [崔明玉] (2002). Kwagŏ sije ŏmiŭi hyŏngsŏnggwa pyŏnhwa [過去時制 語尾의 形 成과 變化]. Chindan hakpo [震檀學報], 94, 135-165. Chindan Hakhoe [震檀學會].

Endo, Y. [遠藤嘉基] (1953/1981). Kunten shiryō to kuntengo no kenkyū (Rev.ed) [訓点資料と 訓点語の研究(改訂版)]. Kyoto: Rinsen Shoten [臨山書店]. 
Fujimoto, Y. [藤本幸夫] (1992). Richō kundoku kō sono ichi -“Bokugyūshi Shūshinketsu” o chūshin ni shite- [李朝訓読放 其一 - 『牧牛子修心訣』を中心にして-]. Chōsen gakuhō [朝鮮学報], 143, 109-218. Chōsen Gakkai [朝鮮学会].

Fujimoto, Y. [藤本幸夫] (1993). Han'gugŭi hundoge taehayŏ [한국의 訓讀에 대하여]. In Sŏul Taehakkyo Taehagwŏn Kugŏ Yŏn'guhoe [서울大學校大學院 國語研究會] (Ed.), An Pyŏngŭi sŏnsaeng hoegap kinyŏm nonch'ong kugŏsa charyowa kugŏhagŭi yŏn'gu [安 秉禧先生 回甲紀念論叢 國語史 資料와 國語學의 研究], 642-649. Seoul: Munhakkwa Chisŏngsa [文學 과 知性社].

Hong, Y. [洪允构] (1994/in press). Kündae kugŏ yŏn'gu ( I ) [近代國語研究( I )]. Unpublished manuscript.

Joho, S. [上保 敏] (2012). Kanbun kundoku no kanten kara mita chūki chōsengo genkai shiryō $n i$ kansuru kenkyu [漢文訓読の観点から見た中期朝鮮語諺解資料に関する研究]. (Doctral thesis, University of Tokyo, Tokyo, Japan).

Kanaoka, S. [金岡照光] (1978). Bukkyō kanbun no yomikata [仏教漢文の読み方]. Tokyo: Shunjūsha [春秋社].

Kanno, H. [菅野裕臣] (1996). Chōsen no gengo to moji [朝鮮の言語と文字]. In Takeda, Y [ 武田幸男] (Ed.), Chōsen no rekishi to bunka [朝鮮の歴史と文化], 99-112. Tokyo: Zaidan Hōjin Hōsō Daigaku Kyōiku Shinkōkai [財団法人放送大学教育振興会].

Kasuga, M. [春日政治] (1938). Koten no kyō ji o megutte [古点の況字をめぐって]. Kokugo to kokubungaku [国語と国文学], 10(1). In Kasuga, M. [春日政治] (1984, pp. 341-364).

Kasuga, M. [春日政治] (1942/1985). Saidaiji bon Konkōmyō Saishōōkyō koten no kokugogakuteki kenkyū (Kasuga Masaji chosakushū - Bekkan-) [西大寺本金光明最勝王 経古点の国語学的研究(春日政治著作集 -別巻-)]. Tokyo: Benseisha [勉誠社].

Kasuga, M. [春日政治] (1984). Kokunten no kenkyū (Kasuga Masaji chosakushū -Dai 6 satsu[古訓点の研究(春日政治著作集 -第六冊-)]. Tokyo: Benseisha [勉誠社].

Kim, M. [김문식], \& Kim, C. [김정호] (2003). Chosŏnŭi wangseja kyoyuk [조선의 왕세자 교육]. Seoul: Kimyŏngsa [김영사].

Kim, W. [金完鎭] (1960). “Nŭngŏmgyŏng Ŏnhae”e kwanhan myŏt kaji kwaje [“능엄경언해”에 관한 몇 가지 과제]. Han'gŭl [한글], 127, 70-83. Han'gŭl Hakhoe [한글학회].

Kim, Y. [金永德] (1952a). Ŏnhaewa pŏnyŏk [諺解와 번 역]. Kugŏ kungmunhak [國語國文學], 1, 15-16. Kugŏ Kungmun Hakhoe [國語國文學會].

Kim, Y. [金永德] (1952b). Ŏnhaewa pŏnyŏk (2) [諺解와 㭛譯 (2)]. Kugŏ kungmunhak [國語 國文學], 2, 10-14. Kugŏ Kungmun Hakhoe [國語國文學會].

Kim, Y. [金永德] (1953). Ónhaewa pŏnyŏk (wan) [諺解와 飜譯 (完)]. Kugŏ kungmunhak [國 語國文學], 3, 13-14. Kugǒ Kungmun Hakhoe [國語國文學會].

Kin, B. [金文京] (2010). Kanbun to higashi Ajia -Kundoku no bunkaken- [漢文と東アジア 訓読の文化圈]. Tokyo: Iwanami Shoten(Iwanami Shinsho) [岩波書店(岩波新書)].

Kosukegawa, T. [小助川貞次] (2009). Higashi Ajia gakujutsu kōryū to shite no kanbun kundoku [東アジア学術交流としての漢文訓読]. Toyama daigaku jinbungakubu kiyō [ 富山大学人文学部紀要], 51,33-44. Toyama Daigaku Jinbungakubu [富山大学人文学部 ]. 
Kosukegawa, T. [小助川貞次] (2010). Dejitaru jidai ni taiōshita kanbun kundoku kenkyū no shakaiteki kyōyū shisutemu no kōchiku [デジタル時代に対応した漢文訓読研究の社会 的共有システムの構築]. Toyama daigaku jinbungakubu kiyō [富山大学人文学部紀要], 52, 87-102. Toyama Daigaku Jinbungakubu [富山大学人文学部].

Nakada, N. [中田祝夫] (1954/1979). Kotenbon no kokugogakuteki kenkyū sōron hen (Rev.ed) [ 古点本の国語学的研究 総論篇(改訂版)]. Tokyo: Benseisha [勉誠社].

Nakamura, T. [中村 完] (1976). Shiteki meiji 'ritō' no gainen to teigi ni tsuite [史的名辞「吏 読」の概念と定義について]. Chōsen gakuhō [朝鮮学報], 78. Chōsen Gakkai [朝鮮学 会]. In Nakamura, T. [中村 完] (1995, pp. 35-55).

Nakamura, T. [中村完] (1995). Ronbun senshū Kunmin Seion no sekai [論文選集 訓民正音 の世界]. Sendai: Sōei Shuppan [創栄出版].

Nam, P. [南豊鉉] (1988). Sŏktok kugyŏrŭi kiwŏne taehayŏ [釋讀口訣의 起源에 대하여]. Kugŏ kungmunhak [國語國文學], 100. Kugǒ Kungmun Hakhoe [國語國文學會]. In Nam, P. [南豊鉉] (1999, pp. 25-34).

Nam, P. [南豊鉉] (1993). Koryŏbon Yugasajironŭi sŏktok kugyŏre taehayŏ [高麗本 瑜伽師地 論의 釋讀口訣에 대하여]. Tongbang hakchi [東方學志], 81, 115-170. Yŏnse Taehakkyo Kukhak Yŏn'guwŏn [延世大學校 國學研究院].

Nam, P. [南豊鉉] (1994). 'Sinyŏk Hwaŏmgyŏng' kwŏn 14ŭi koryŏ sidae sŏktok kugyŏl [ 『新 譯華嚴經』卷 14 의 高麗時代 釋讀口訣]. Kungmunhak nonjip [國文學論集], 14 .

Tan'guk Taehakkyo Kugŏ Kungmun Hakkwa [檀國大學校 國語國文學科]. In Nam, P. [ 南豊鉉] (1999, pp. 167-199).

Nam, P. [南豊鉉] (1997). Han'guge isŏsŏŭi kugyŏl yŏn'guŭi hoegowa chŏnmang [韓國에 있어서의 口訣研究의 回顧와 展望]. Kuntengo to kunten shiryō [訓点語と訓点資料], 100. Kuntengo Gakkai [訓点語学会]. In Nam, P. [南豊鉉] (1999, pp. 35-63).

Nam, P. [南豊鉉] (1999). Kugŏsarŭl wihan kugyŏl yŏn'gu [國語史를 위한 口訣研究]. Seoul: T’aehaksa [太學社].

Nam, P. [南豊鉉], \& Sim, C. [沈在箕] (1976). Kuyŏk Inwanggyŏngŭi kugyŏl yŏn'gu (il) [舊譯 仁王經의 口訣研究 (一)]. Tongyangak [東洋學], 6. Tan'guk Taehakkyo Tongyanghak Yŏn'guso [檀國大學校 東洋學研究所]. In Nam, P. [南豊鉉] (1999, pp. 67-137).

O, M. [오미영] (2004). 16 segi hanil yanggugŭi Nonŏ ihae [16 세기 한일 양국의 논어 이해]. Irŏ ilmunhak yŏn'gu [日語日文學研究], 50(1), 29-49. Han'guk Irŏ Ilmun Hakhoe [韓國 日語日文學會].

Ogura, S. [小倉進平] (1920). Kokugo oyobi chōsengo no tame [国語及朝鮮語のため]. Keijo: Utsuboya Shosekiten [ウツボヤ書籍店]. In Ogura, S. [小倉進平] (1975, pp. 1-314).

Ogura, S. [小倉進平] (1934). Chōsengo to nihongo (Kokugo kagaku kōza -IV - Kokugogaku) [ 朝鮮語と日本語(国語科学講座 -IV- 国語学)]. Tokyo: Meiji Shoin [明治書院]. In Ogura, S. [小倉進平] (1975, pp. 315-378).

Ogura, S. [小倉進平] (1975). Ogura Shinpei hakase chosakushū 4 [小倉進平博士著作集 4]. Tokyo: Heibonsha [平凡社].

Ogura, S. [小倉進平], editted by Kono, R. [河野六郎] (1964). Zōtei hochū chōsen gogakushi [増訂補注 朝鮮語学史]. Tokyo: Tōkō Shoin [刀江書院].

Osada, N. [長田夏樹] (1980). Nitchō ryōkoku kanbun kundoku tangen (jō) [日朝両国漢文訓 読探源(上)]. Chōsen gakuhō [朝鮮学報], 97, 13-24. Chōsen Gakkai [朝鮮学会]. 
Osada, N. [長田夏樹] (1981). Nitchō ryōkoku kanbun kundoku tangen (ge) [日朝両国漢文訓 読探源(下)]. Chōsen gakuhō [朝鮮学報], 99・100, 91-108. Chōsen Gakkai [朝鮮学会].

Pak, C. [朴鎭浩] (2009). Kankoku no tento kuketsu no dokuhō ni tsuite -Kasuga Masaji "Saidaiji bon Konkōmyō Saishōōkyō koten no kokugogakuteki kenkyū" tono taihi o tsūjite- [韓国の点吐口訣の読法について - 春日政治『西大寺本金光明最勝王経古点 の国語学的研究』との対比を通じて-]. Kuntengo to kunten siryō [訓点語と訓点資料], 123, 10-19. Kuntengo Gakkai [訓点語学会].

Shibu, S. [志部昭平] (1983). Otsugaiji bon Ryōgonkyō Genkai ni tsuite [乙亥字本楞篇経彥解 について]. Chōsen gakuhō [朝鮮学報], 106, 1-24. Chōsen Gakkai [朝鮮学会].

Sin, K. [申景澈] (1993). Kugŏ chasŏk yŏn'gu [國語 字釋 研究]. Seoul: T’aehaksa [太學社].

Tsukishima, H. [築島 裕] (1963). Heian jidai no kanbun kundokugo ni tsukite no kenkyū [平安 時代の漢文訓読語につきての研究]. Tokyo: Tōkyō Daigaku Shuppankai. [東京大学出 版会].

Ushijima, T. [牛島徳次] (1956). Joji kō -Sōdai izen- [助字考 -宋代以前-]. Tōkyō kyōiku daigaku bungakubu kiyō kokubungaku kanbungaku ronsō [東京教育大学文学部紀要国 文学漢文学論叢], 7, 1-69. Tōkyō Kyōiku Daigaku Bungakubu [東京教育大学文学部].

Yi, K. [李基文] (1972). Hanchaŭi sŏge kwanhan yŏn'gu [漢字의 釋에 關한 研究]. Tonga munhwa [東亞文化], 11. Seoul: Sŏul Taehakkyo Tonga Munhwa Yŏn'guso [서울大學校 東亞文化研究所]. In Yi, K. [李基文] (1991, pp. 255-288).

Yi, K. [李基文] (1991). Kugŏ ŏhwisa yŏn'gu [國語 語彙史 研究]. Seoul: Tonga Ch'ulp'ansa [ 東亞出版社].

Yi, S. [이상훈] (2009). Pusa 'hamulmyŏ'ŭi ŭimi [부사 '하물며'의 의미]. In Sŏul taehakkyo kugŏ kungmun hakkwa [서울대학교 국어국문학과] (ed.), Kugŏhak nonchip [국어학논집], 6, 209-222. Seoul: Tosŏch'ulp'an Yŏngnak [도서출판 역락].

\section{Reference Tools}

Hwang, S. [황선엽], Yi, C. [이전 경], Ha, K. [하귀녀], Yi, Y. [이용], Pak, C. [박진호], Kim, S. [김성주], ... Sŏ, H. [서형 국] (2009). Sŏktok kugyŏl sajŏn [釋讀구결사전]. Seoul: Pangmunsa [박문사].

Luó Z. [罗竹风] (Ed. in chief.), Hànyǔ dàcídiăn biānjí wěiyuánhuì. [汉语大词典编辑委员会], \& Hànyǔ dàcídiăn biānzuănchù. [汉语大词典编纂处] (Eds.) (1986-1994/2008). Hànyǔ dàcídiăn [汉语大辞典]. Shanghai: Shànghăi Císhū Chūbănshè [上海辞书出版社].

Morohashi, T. [諸橋轍次] (1966-1968). Dai kanwa jiten (shukusha ban) [大漢和辞典(縮写版 )]. Tokyo: Taishūkan Shoten [大修館書店].

Pak, C. [朴在淵] (2002). Chungjo taesajŏn [中朝大辭典]. Asan: Chunghan Pŏnyŏk Munhŏn Yŏn'guso - Sŏnmun Taehakkyo Ch'ulp'anbu [中韓翻譯文獻研究所・鮮文大學校 出版 部].

Yoshida, K. [吉田金彦], Tsukisima, H. [築島 裕], Ishizuka, H. [石塚晴通], \& Tsukimoto, M. [月本雅幸] (eds.) (2001). Kuntengo jiten [訓点語辞典]. Tokyo: Tōkyōdō Shuppan[東京 堂出版]. 
Zhāng, X. [章錫深] (Ed.) (1954/2004). Zhùzì biànlue (Páiyìnběn) [助字辨略(排印本)]. Beijing: Zhōnghuá Shūjú [中華書局]. 